\title{
Phelan-McDermid Syndrome
}

National Cancer Institute

\section{Source}

National Cancer Institute. Phelan-McDermid Syndrome. NCI Thesaurus. Code C157124.

An autosomal dominant condition caused by mutation(s) and or deletion of the SHANK3 gene, encoding SH3 and multiple ankyrin repeat domains protein 3. It is characterized by variable features, which may include intellectual disability, autism spectrum disorder, developmental delay and mild dysmorphic features. 